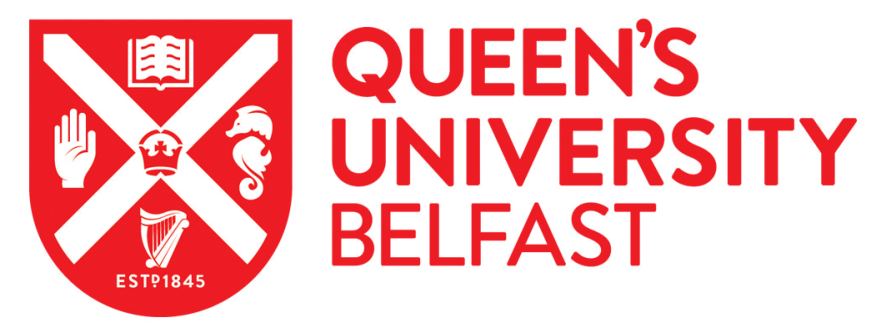

\title{
Environmental Operations Management and its links with Proactivity and Performance: A study of the UK Food Industry
}

Graham, S., \& Potter, A. (2015). Environmental Operations Management and its links with Proactivity and Performance: A study of the UK Food Industry. International Journal of Production Economics, 170(Part A), 146159. https://doi.org/10.1016/j.ijpe.2015.09.021

Published in:

International Journal of Production Economics

\section{Document Version:}

Peer reviewed version

\section{Queen's University Belfast - Research Portal:}

Link to publication record in Queen's University Belfast Research Portal

\section{Publisher rights}

(c) 2015 Elsevier B.V. All rights reserved

This manuscript version is made available under the CC-BY-NC-ND 4.0 license http://creativecommons.org/licenses/by-nc-nd/4.0/ which permits distribution and reproduction for non-commercial purposes, provided the author and source are cited.

\section{General rights}

Copyright for the publications made accessible via the Queen's University Belfast Research Portal is retained by the author(s) and / or other copyright owners and it is a condition of accessing these publications that users recognise and abide by the legal requirements associated with these rights.

Take down policy

The Research Portal is Queen's institutional repository that provides access to Queen's research output. Every effort has been made to ensure that content in the Research Portal does not infringe any person's rights, or applicable UK laws. If you discover content in the Research Portal that you believe breaches copyright or violates any law, please contact openaccess@qub.ac.uk. 


\section{Introduction}

As environmental concerns have grown in recent years, firms have directed increasing attention to the environmental impact of their operations (Hofer et al., 2012). Research interest in environmental issues at the operations level of firms is at an all-time high with numerous studies investigating various different aspects of this development (Montabon et al., 2007; Yang et al., 2010; Schoenherr, 2012; Thoumy and Vachon, 2012). Two particularly prominent themes that have emerged from this research are the environmental orientation of firms and the performance outcomes that can arise from environmental management (Akin-Ates et al., 2012; De Burgos-Jiminez et al., 2014). To date these themes have often been explored relatively independently from each other, yet it is of interest to consider the potential links between the two as intuitively it is not unreasonable to assume that orientation will have an impact on performance outcomes. More specifically, it would be interesting to explore the question of whether firms that implement pro-active environmental practices capture better performance benefits than firms who are more reactive and limited in their approach to environmental management (Hart, 1995; Hart and Dowell, 2011). The purpose of this study is to explore the link between a pro-active environmental orientation, which is normally reflected in the type of environmental practices that are pursued, and organisational performance.

Important work has already been done on environmental orientation and the performance outcomes associated with pursuing environmental strategies. The matter of environmental orientation has been addressed in a number of studies (Henriques and Sadorsky, 1999; Buysse and Verbeke, 2003; Humphreys et al., 2003; Sharma and Henriques, 2005; Akin-Ates et al., 2012; De Burgos-Jimenez et al., 2014; Lo, 2014). Two of the most prominent orientations outlined in the literature are reactive and pro-active orientations. A reactive response is indicative of a short-term, compliance-based view, which regards environmental management as a burden requiring minimal investment (Akin-Ates et al., 2012; Lo, 2014). In contrast, a pro-active response occurs when firms have a desire to go beyond compliance in the hope (in most cases) of securing added value and other benefits (Garces-Ayerbe et al., 2012; Lo, 2014; De Burgos-Jiminez et al., 2014). The potential benefits of a pro-active orientation are becoming 
increasingly evident (Akin-Ates et al., 2012; De Burgos-Jiminez et al., 2014), yet the research assessing its links with performance has not been systematic.

Moreover, studies on the link between environmental activity and organisational performance generate mixed results (Hart and Ahuja, 1996; Rao and Holt, 2005; Montabon et al., 2007; Paulraj and de Jong, 2011; De Giovanni, 2012; Dam and Petkova, 2014). This suggests that a link between a firm's orientation toward environmental management and organisational performance requires further indepth investigation and represents an important research gap in the extant literature. One potential explanation for the inconclusive results is that different organisational practices, procedures and policies influence the relationship between orientation and performance. For example, some studies focus on specific operational practices such as waste and emission reduction, recycling and remanufacturing (Hart and Ahuja, 1996; Sroufe, 2003; Montabon et al., 2007); others include practices related to the environmentally conscious design of products (Zailani et al., 2012); while others still focus on the links between environmental management systems and performance (Darnall et al., 2008). There is also variation in the level at which practices are assessed. Some studies consider only internal organisational practices (Sroufe, 2003; Montabon et al., 2007; Yang et al., 2011), whereas, others, concentrate on supply chain practices (Zhu and Sarkis, 2004; Vachon and Klassen 2008; Green et al., 2012; Dam and Petkova, 2014). Assessment of a diverse range of practices within different organisational contexts invariably increases the likelihood of uncertainty over the link between environmental practices and performance as it is often the case that certain practices are linked while others are not. As highlighted by Vachon and Klassen (2008), a large part of the reason why studies focus on different practices is the absence of agreed frameworks to guide the research (Iwata and Okada, 2011; Beske et al., 2014). To counteract this shortcoming, this study develops a theoretical framework, grounded in the Natural Resource-Based view (NRBV) to link together the dimensions of environmental proactivity, practices and performance.

The main objective of this study is to contribute to the on-going discussions regarding environmental orientation and performance (Akin-Ates et al., 2012; De Burgos-Jiminez et al., 2014). The study makes four important contributions. First, it considers how a pro-active environmental orientation might 
translate into operational practices. In doing so, it builds upon an earlier study by Bowen et al. (2001) that tests the link between proactivity and environmental practices with suppliers and calls for further studies to examine practices at other stages of the supply chain. Second, treating environmental proactivity as a stand-alone concept as opposed to a subset of wider environmental practices or strategies (Buysse and Verbeke, 2003; Lopez-Gamero et al., 2009; Sarkis et al., 2010) is novel as it delineates between the concepts of proactivity, practices and performance when exploring their interrelationships (De Burgos-Jimenez et al., 2014). Third, employing a theoretical framework better positions the study to investigate the link between practices and performance. Finally, the study deepens understanding of environmental management in the context of the food industry, which faces unique and complex environmental challenges (Maloni and Brown, 2006; Li et al., 2014).

The paper is organized as follows. Section 2 reviews the literature on the natural resource-based view to develop a set of hypotheses to explore the link between the environmental orientation of firms and organisational performance. Following this, section 3 provides an explanation of the research methods employed by the study. Then, section 4 presents and discusses the results from the multiple regression analysis. Section 5 concludes the study with a summary of the key findings and a discussion of their importance to the environmental operations management literature.

\section{Literature review and hypothesis development}

The Natural Resource-Based View (NRBV) has emerged upon recognition that the Resource-Based View (RBV) does not take full account for the impact of the natural environment on business (Hart, 1995; Hart and Dowell, 2011). The core argument of the NRBV is that strategy and competitive advantage will be 'rooted in capabilities that facilitate environmentally sustainable economic activity' (Hart, 1995: 991). It emphasises that firms can capture competitive advantage if pro-active consideration is given to the natural environment when designing and operating production processes (Hart and Dowell, 2011; Thoumy and Vachon, 2012; Wong et al., 2012): The NRBV suggests that using particular sets of practices consistent with a pro-active approach to environmental management 
can enhance organisational performance (Hart, 1995; Hart and Dowell, 2011; Wong et al, 2012). In its original form, the NRBV focussed on three broad groupings of practices; pollution prevention, product stewardship and sustainable development (Hart, 1995). Pollution prevention represents environmental efforts at the internal operations level while, product stewardship moves beyond this to the supply chain level as environmental impact of a product's life cycle is considered. This requires a level of engagement with the external stakeholders involved in the production process such as suppliers and customers (Hart, 1995). Sustainable development moves further beyond this by seeking to engage with a broader range of external stakeholders such as competitors or governments who are not directly involved in the production process. This level of external engagement enables them to shape legislation and become environmental leaders within their industry (Hart, 1995; Hart and Dowell, 2011). Subsequent development of the NRBV framework has led to a breakdown of the concept of sustainable development into two further categories, namely, clean technology and bottom of the pyramid practices (Hart and Dowell, 2011). This breakdown reflects the different research directions taken with regard to sustainable development since the introduction of the NRBV and encourages more focussed research attention. To date, sustainable development has received limited research attention in comparison to pollution prevention and product stewardship (Hart and Dowell, 2011).

Within the extant literature, some empirical studies consider the antecedents of pro-active environmental approaches (Buysse and Verbeke, 2003), others concentrate on the facilitators of environmental approaches (Chan, 2005) and yet others investigate the link between environmental approaches and performance (Christmann, 2000; Vachon and Klassen, 2008). Because these studies mostly explore narrow features of the NRBV in isolation, few reliable conclusions can be drawn from their findings about the complex inter-relationships between environmental proactivity and organisational performance (Chan, 2005). Recent studies have sought to shed more light on the saliency of the NRBV by examining the interdependent links between proactivity, practices (activities) and performance (Akin-Ates et al., 2012; De Burgos-Jiminez et al., 2014). 
Building upon the NRBV and recent research in this area, we develop and empirically test a framework that explores the interrelationships between proactivity, practices and performance (see Figure 1). Our framework is consistent with the NRBV's key proposition that proactive environmental efforts may lead to sources of competitive advantage. Two key dimensions of the NRBV are assessed in the framework, namely, pollution prevention and process stewardship. Sustainable development is not considered in this study as more research is needed to assess how it translates into practice and the extent to which firms are pursuing this level of external stakeholder engagement (Hart and Dowell, 2011). Further, the dimensions of pollution prevention and stewardship are considered to capture environmental practices at the operations and supply chain levels, consistent with the objectives of this study. As we are seeking to assess environmental efforts of typical manufacturing firms as opposed to environmental leaders, consideration of efforts in relation to sustainable development is beyond the scope of this study.

From a theoretical perspective the framework addresses two key areas in relation to the NRBV. First, the influence of a pro-active environmental orientation on pollution prevention and process stewardship is assessed, followed by examination of links with organisational performance (Hart, 1995; Hart and Dowell, 2011). The variables included in the framework were selected based on their prominence in the extant literature as well as their relevance to the NRBV.

\subsection{Environmental proactivity}

Pro-active and reactive approaches to environmental management are often seen as distinct from each other (Buysse and Verbeke, 2003). One distinction relates to the timing of response to environmental issues. The former approach involves pre-planned preventative action with the objective of avoiding negative environmental impact where possible, while the latter approach is more post-hoc in the sense that a response is often triggered as a result of an undesired environmental impact that has to be managed and controlled (Zailani et al., 2012). Proactivity involves a dimension of intentionality whereby active engagement with the environment is pursued on an on-going basis in order to minimise and avoid the occurrence of undesired outcomes. Defined as "a tendency to go further than complying with legislation 
or the industry standard" (Garces-Ayerbe et al., 2012: 190), the concept of environmental proactivity is prominent within the literature on environmental management (Bowen et al., 2001; Buysse and Verbeke, 2003; Sharma et al., 2007; Jeffers, 2010; Akin-Ates et al., 2012; De Burgos-Jiminez et al., 2014). So far, studies mostly explore the antecedents and outcomes of environmental proactivity. With regard to antecedents, stakeholder pressure (Henriques and Sadorsky, 1999; Buysse and Verbeke, 2003; Garces-Ayerbe et al., 2012), firm size (Darnall et al., 2010), resources and capabilities (Sharma et al., 2007), conditions in the external environment (Murillo-Luna et al., 2011) and perceived value (GarcesAyerbe et al., 2012) are highlighted as important. Regarding outcomes, studies assessing its link with financial performance indicate the potential for a pro-active response contributing to the bottom line (Gonzalez-Benito and Gonzalez-Benito, 2005; Akin-Ates et al., 2012; De Burgos-Jiminez et al., 2014). However, the relationship between environmental proactivity, pollution prevention and process stewardship has yet to be investigated empirically and represents an important gap in the extant literature.

\subsubsection{Environmental proactivity and pollution prevention}

A link between proactivity and pollution prevention is suggested in the NRBV as this approach is viewed as a 'beyond compliance' response to environmental concerns (Hart, 1995; Hart and Dowell, 2011). Pollution prevention is normally seen as an approach that firms use internally to reduce levels of waste or emissions on a continuous improvement basis (Buysse and Verbeke, 2003; Michalisin and Stinchfield, 2010). It seeks to optimise resource consumption and prevent waste and emissions consistent with the financial targets of the firm (Dias-Sardinha and Reijnders, 2001; 2002). The aim of pollution prevention is to eliminate pollution at its source in the production process (Thoumy and Vachon, 2012; Hoque and Clarke, 2013). This is usually done through modifying products and processes as well as encouraging the use of non-toxic or less toxic substances in production (Munguia et al., 2010; Schoenherr, 2012). Its focus on prevention assumes a degree of proactivity which sets it apart from more traditional end-of-pipe solutions that tend to deal with pollution problems after they have occurred (Gonzalez-Benito and Gonzalez-Benito, 2005; Munguia et al., 2010). While the concepts of proactivity and pollution prevention have been linked within the literature (Hart, 1995; Russo and 
Fouts, 1997; Buysse and Verbeke, 2003; Murillo-Luna et al., 2011), these links appear to be mostly conceptual. In particular, we are not aware of any studies that have empirically tested for a direct link between a pro-active environmental orientation and pollution prevention. Addressing this research gap in the literature is important, but to do so requires the concept of pollution prevention to be broken down into more specific and measurable practices. Only then will it be feasible to assess its link with proactivity. Unpacking pollution prevention into waste and emissions practices is a useful way to proceed given that these are the main constituent parts of pollution prevention (Hart, 1995, 1997; Michalisin and Stinchfield, 2010).

Waste and energy emissions are highlighted as key sources of pollution within the literature on environmental management (Bansal, 2002; Sroufe, 2003; Montabon et al., 2007; Tate et al., 2010). A firm's orientation to the environment will influence their response to the problem of pollution. For example, a reactive orientation may lead to compliance-based pollution control practices, which normally focus on the short term goal of keeping pollution levels at a predetermined limit: no real effort is made to improve pollution levels beyond what is required. In contrast, the pre-planned actions associated with a pollution prevention approach will in most cases require some degree of proactivity on the part of the firm. The NRBV encourages pro-active engagement with the environment and suggests that it can be expressed through different practices, many of which fall into the category of pollution prevention such as energy reduction and waste reduction (Montabon et al., 2007; Tate et al., 2010). Thus, the following hypotheses are developed;

Hypothesis 1a: Environmental proactivity has a positive influence on energy reduction practices. Hypothesis 1b: Environmental proactivity has a positive influence on waste reduction practices.

\subsubsection{Environmental proactivity and process stewardship}

The NRBV suggests that firms can extend their internal pollution prevention efforts beyond their organisational boundaries by working with other actors in the supply chain (Vachon and Klassen, 2008; 
Hart and Dowell, 2011). Stewardship is the term used to capture these efforts (Wong et al., 2012). Firms adopting a stewardship approach express a long term commitment to the environment through pursuing environmental efforts across the supply chain (Hart, 1995). Stewardship activities can be applied either to a product being developed (Hart, 1995; Hart and Dowell, 2011) or the process through which it is developed (Wong et al., 2012). As the environmental impact of the production process is the main focus of this study, we are solely concerned with process stewardship. Process stewardship represents a process-oriented environmental approach that seeks to reduce negative environmental impacts arising from operating activities across all stages of the supply chain (Wong et al., 2012). To be effective, it requires all actors and firms across the supply chain involved in the production process to be aligned in their endeavours to improve environmental sustainability (Mena et al., 2014). Responsibility for securing supply chain integration or alignment to advance process stewardship normally falls on the lead firm. It usually seeks to do so in one of two ways. One option is to follow a risk minimisation approach and monitor suppliers and customers. This involves setting standards and monitoring the extent to which they are adhered to across the supply chain (Vachon and Klassen, 2006). An alternative approach is to develop collaborative relationships with supply chain partners and actively engage in joint problem solving activities (Vachon and Klassen, 2008).

Thus, collaboration implies actors working together for mutual gain in the absence of control mechanisms (Squire et al., 2009). Fostering cooperation of this type requires information sharing and communication among the parties as well as a clear understanding of the respective responsibilities and capabilities of each party (Vachon and Klassen, 2008; Wiengarten et al., 2013; Blome et al., 2014; Grekova et al., 2014). Customers and suppliers normally commit to collaborative arrangements because they perceive potential gains such as, risk sharing, access to complementary resources, reduced transaction costs and improved competitive advantage (Cao and Zhang, 2011). Previous studies of supply chain environmental collaboration highlight the potential for such benefits to be captured (Vachon and Klassen, 2008; Hollos et al., 2012; Blome et al., 2014). 
Supplier environmental collaboration represents the input stage of the process stewardship approach. Ensuring that components and materials used in the production process meet more stringent environmental requirements has become more important as lead firms are being held increasingly accountable for environmentally irresponsible behaviour of other actors in their supply chain (Rao and Holt, 2005; Christopher, 2010; Hoejmose et al., 2013, Lo, 2014). Thus, it is important for firms to consider the environmental impact of processes upstream in their supply chain. Environmental collaboration can also take place with customers downstream in the supply chain (Vachon and Klassen, 2008; Blome et al., 2014). For example, if products need to be disposed of in a specific way it is important for a firm and its customers work together to ensure that all relevant information is shared (Blome et al., 2014).

All in all, supply chain collaboration is highly complex, requiring strategy alignment among the involved parties (Vachon et al., 2009; Wiengarten et al., 2011). In developing such an approach, a proactive orientation is important (Hart, 1995; Bowen et al., 2001; Pagell and Wu, 2009). However, research on the drivers of environmental collaboration has been limited to date (de Leeuw and Fransoo, 2009). In spite of this, it can be reasonably assumed that this alignment does not emerge spontaneously, but rather requires commitment and planned coordinated action with regard to environmental management. Thus, the following hypotheses are developed;

H2a: Environmental proactivity has a positive influence on environmental collaboration with suppliers.

H2b: Environmental proactivity has a positive influence on environmental collaboration with customers.

\subsection{The link between environmental practices and organisational performance}

In order to assess the merits of a pro-active approach to environmental management it is important to examine organisational performance across environmental and operational dimensions. This enables exploration of the extent to which these practices lead to positive outcomes that might contribute to competitive advantage as proposed in the NRBV (Hart, 1995). Environmental performance can be 
viewed as the extent to which firms achieve the objectives set for environmental management efforts (De Burgos-Jimenez et al., 2014). Cost performance is a commonly used measure of operational performance and has been considered alongside environmental performance in a number of studies on environmental management (Rao and Holt, 2005; Vachon and Klassen, 2008). Improving cost performance is a key objective for most operations and is considered as the second key performance dimension within this study. The potential for pollution prevention and process stewardship to enhance both environmental and operational performance is noted within the literature (Hart, 1995; Hart and Ahuja, 1996; Christmann, 2000; King and Lennox, 2001; Paulraj and de Jong, 2011; Giminez and Tachizawa, 2012; Kaipia et al., 2013). Environmental performance improvements can derive from the more effective utilisation of resources and improved efficiency associated with pollution prevention and process stewardship practices (Rao and Holt, 2005). Cost improvements can also emerge as a result of greater efficiency and reduction of waste and emissions (Rao and Holt, 2005). Benefits such as improved environmental and cost performance are a key incentive for many firms in adopting environmental practices (Bowen et al., 2001).

\subsubsection{Pollution prevention and organisational performance}

A number of studies suggest that firms adopting a pollution prevention approach are likely to experience environmental and operational benefits (King and Lennox, 2001; Wu and Pagell, 2011). The concept of pollution prevention outlined in the NRBV encompasses a broad range of internal environmental practices and could be operationalised in different ways (Hart, 1995; Hart and Dowell, 2011). Empirical support for a link between internal environmental practices aimed at pollution prevention and dimensions of organisational performance has been provided by a number of studies (Zhu and Sarkis, 2004; Paulraj and de Jong, 2011; De Giovani, 2012; Giminez et al., 2012). Improvements in environmental performance derive from internal efforts to reduce negative environmental impacts within the production process (Rao and Holt, 2005). Pollution can be viewed as a form of waste, indicating inefficiency within the production process. Thus, attempts to reduce pollution should generate not only environmental improvements but also enhance efficiency in the production process (da Silva and de Medeiros, 2004). Creating a more efficient process through pollution prevention has 
the potential to both improve environmental performance and reduce production costs substantially (Hart and Ahuja, 1996; Rao and Holt, 2005; Porter and Kramer, 2006). The suggestion that the adoption of pollution prevention, even at a basic level, may lead to environmental and economic benefits indicates that it may be beneficial for firms to implement energy and waste reduction practices (Griffith and Bhutto, 2009). Thus, the following hypotheses are developed;

H3a: Energy reduction practices are positively associated with environmental performance.

H3b: Waste reduction practices are positively associated with environmental performance.

H3c: Energy reduction practices are positively associated with cost performance.

H3d: Waste reduction practices are positively associated with cost performance.

\subsubsection{Process stewardship and organisational performance}

The benefits that can arise from a process stewardship approach have been suggested conceptually (Hart, 1995), but empirical research on this claim is still underdeveloped (Hart and Dowell, 2011). Some studies on environmental management consider the relationship between certain supply chain environmental practices and organisational performance (Zhu and Sarkis, 2004; Vachon and Klassen, 2008). While process stewardship practices are not explicitly explored, these existing studies generate some insight into the relationship between environmental practices and performance outcomes at the supply chain level. Of these studies, a number provide empirical support for a positive relationship between various environmental supply chain practices and organisational performance (Rao and Holt, 2005; Vachon and Klassen, 2008; Giminez et al., 2012). As far as we are aware, only one study appears explicitly to assess the link between process stewardship and organisational performance (Wong et al., 2012). This study by Wong et al. (2012) provides some preliminary empirical support for a positive relationship between process stewardship and environmental and cost performance.

We consider process stewardship to consist of both supplier and customer collaboration, which together are considered as the crystallization of pro-active efforts to improve environmental performance. This view is consistent with the emphasis placed by the NRBV on integrating multiple stakeholders involved 
in the process with regard to environmental management efforts (Hart, 1995). Thus, it is appropriate to consider suppliers and customers as key actors in environmental management efforts. Relational resources are particularly important facilitators of environmental collaboration and the degree to which these are aligned and used effectively can lead to favourable performance outcomes (Vachon and Klassen, 2008; Blome et al., 2014). Empirical evidence suggests that collaborative practices are more effective in improving the triple bottom line than monitoring and assessment practices (Giminez et al., 2012; Giminez and Tachizawa, 2012).

A number of empirical studies identify improvements in environmental performance resulting from collaborative environmental activities between lead firms and suppliers (Zhu and Sarkis, 2004; Rao and Holt, 2005; Vachon and Klassen, 2008; Green et al., 2012; Blome et al., 2014). Firms working together with suppliers to tackle environmental concerns can share skills and capabilities developed through their own internal environmental activities, thus boosting efforts at improving supply chain environmental performance (Green et al., 2012). As a result, environmental concerns can be addressed and minimised at the source upstream in the supply chain, alleviating negative effects throughout the production process. Moreover, if collaborative efforts with suppliers lead to more efficient processes, further gains can be captured, particularly in terms of cost reductions. Some studies emphasize this link between environmental collaboration with suppliers and improvements in environmental and cost performance (Geffen and Rothenberg, 2000; Klassen and Vachon, 2003; Rao and Holt, 2005; Vachon and Klassen, 2008; Paulraj, 2011; Wong et al., 2012). Thus, the following hypotheses are developed;

H4a: Supplier environmental collaboration is positively associated with environmental performance. H4b: Supplier environmental collaboration is positively associated with cost performance.

Collaboration with customers is another supply chain practice linked to improved organisational performance (Elofson and Robinson, 2007; Vachon and Klassen, 2008; Cannella and Ciancimino, 2010). Increasingly, firms are fostering collaboration with customers in response to environmental challenges (Beamon, 2008). The aim is to develop joint solutions to the environmental problems faced 
by both parties (Vachon and Klassen, 2008). Environmental challenges at the customer side of the supply chain may relate to transport and distribution or recovery and disposal of waste (Webster and Mitra, 2007; Zailani et al., 2012). In response to these challenges some firms work with their customers to develop environmentally responsible transport and distribution systems (Goldsby and Stank, 2000; Preuss, 2005; Halldorsen et al., 2009). Within the broader supply chain literature, the practice of customer collaboration is linked to a number of operational benefits (Devaraj et al., 2007; Cao and Zhang, 2011; Wiengarten, 2013). While studies on the link between customer environmental collaboration and performance are fairly limited, the empirical results that exist suggest that similar benefits can be obtained in the context of environmental management (Hollos et al., 2012; Blome et al., 2014). Thus, the following hypotheses are developed;

H4c: Customer environmental collaboration is positively associated with environmental performance.

H4d: Customer environmental collaboration is positively associated with cost performance.

Figure 1 Research framework

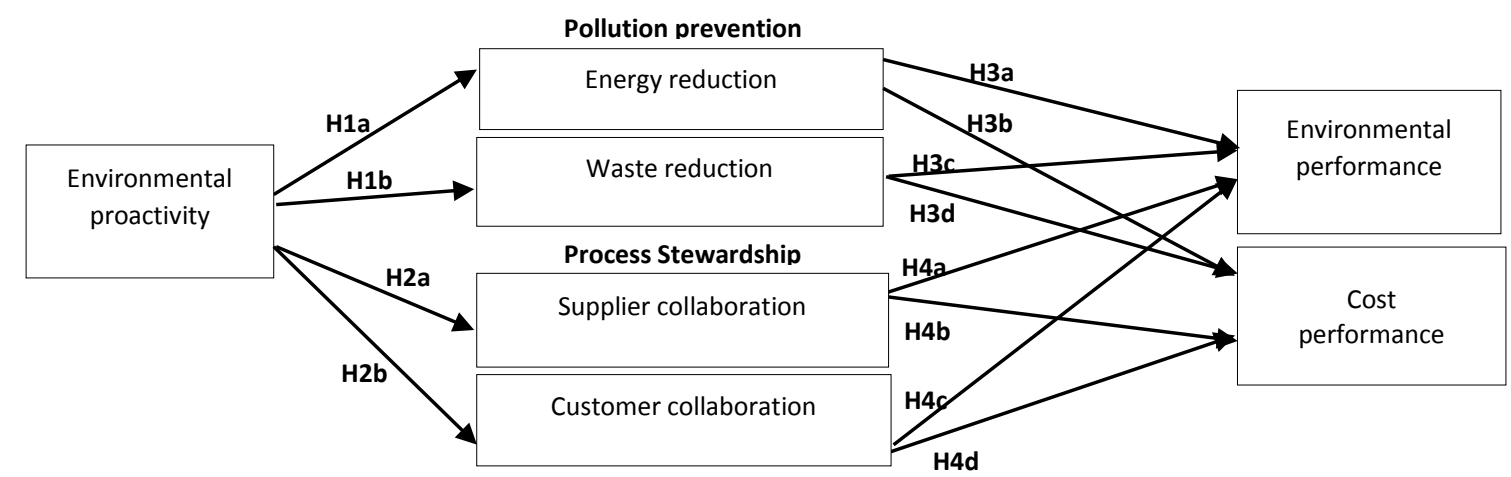

\section{Research design}

\subsection{Sample frame}

A survey of the food industry in the United Kingdom was used to gather the data for this study. A focused, single-industry approach was considered appropriate as it enabled the control of industry specific factors that might influence results (Vachon and Klassen, 2008). Environmental pressures and responses in the food industry have been considered unique, making it an interesting business context 
for the study (Mattas and Tsakiridou, 2010; Mahalik and Nambiar, 2010). A survey instrument as well as a semi-structured interview schedule for managers in food producing firms were developed to collect data for the study. A total of six semi-structured interviews were conducted with environmental and operations managers in order to develop and refine the survey questionnaire. Once completed, the survey instrument was subjected to pilot tests with a further six managers and six senior academics to ensure quality (Fowler, 1993; Diamantopoulos et al., 1994; Drucker, 2000). A number of revisions were made to the survey as a result of this process.

A sample of 1200 food processing firms with a minimum of 50 employees was compiled from a data set purchased from William Reed media. All of the firms included in the sample operate within the Standard Industrial Classification (SIC) DA 15 that covers the food industry in the UK, including the manufacture of food products and beverages. Dillman's (2007) tailored design method was adhered to in the design and distribution of the questionnaire. The survey was sent out in three waves with follow up phone calls to encourage responses (Forza, 2002). A total of 149 responses were received generating a response rate of $12.4 \%$, consistent with other studies in the area (e.g. Melnyk et al., 2003; Darnall et al., 2008; Paulraj, 2011).

Standard statistical tests for response bias were conducted to ensure the quality of the data prior to analysis. Firstly, a bivariate correlation comparing responses to the first mailing with responses to the second and third mailings was conducted to test for non-response bias (Armstrong and Overton, 1977; Etter and Perneger, 1997). Following this, sensitivity analyses were conducted to assess for significant variations in responses across different sub-industry groups and respondent job titles. The results suggest that response bias is not a concern for the data. Further, to ensure that respondents were knowledgeable about environmental practices in the production process, a question on their level of knowledge was included at the end of the survey. An average knowledge score of $84.2 \%$ generates confidence that the responding managers were knowledgeable about the issues under investigation. 
A seven point Likert scale anchored from either "strongly agree" to "strongly disagree” or "not at all” to "a very great extent” was used to assess the responses to each of the questions. Further details of all the measures used are available in the Appendix.

Environmental proactivity- is measured using a five-item scale developed by Bowen et al. (2001). This measure focuses on the extent to which environmental concerns are given a high priority by the management of responding firms, the extent to which they go beyond compliance, lead their industry and manage environmental risks.

Pollution prevention- Two new scales comprising energy reduction and waste reduction were developed to measure this concept. These were informed by studies on environmental management in a food industry context (Maloni and Brown, 2006; Pullman et al., 2009) as well as online information from the Department for Environment, Food and Rural Affairs (DEFRA) and the Food and Drink Federation (FDF). Together these sources generate insight into the key environmental issues and challenges faced by firms operating in the UK food industry and the efforts being taken to prevent pollution within this context.

Process stewardship- Existing scales from the literature were used to measure the elements making up this concept. A four-item scale was replicated from a study by Paulraj (2008) to measure the level at which responding firms engaged in supplier environmental collaboration. A five-item scale was replicated from a study by Vachon and Klassen (2008) to measure the level of environmental collaboration with customers.

Environmental performance- A new five-item scale was developed to measure environmental performance. Again, this was informed by studies on environmental management in a food industry context (Maloni and Brown, 2006; Pullman et al., 2009) backed up by online information from DEFRA and FDF. There was also an attempt to link the performance outcomes with the practices in the model. 
Cost performance- We adapted Vachon and Klassen’s (2008) scale to measure cost performance. A four-item scale was constructed which focuses on the extent to which cost related improvements derive from environmental practices.

\subsection{Exploratory factor analysis}

Exploratory factor analysis (EFA) using orthogonal rotation was conducted on the scales to determine their overall effectiveness as measures of the concepts included in the theoretical framework in Figure 1, (Hair et al., 2006). Bartlett's test for spherecity as well as Kaiser Meyer Olkin’s (KMO) test were also conducted for each of the variable groups in order to assess the significance and strength of relationships among the items comprising the variables (Vogt, 2005). The variables were put into the orthogonal rotation in groups of three (see Appendix 1).

Convergence and discriminant validity were assessed within the EFA. All but one of the standardised loadings were statistically significant and above the .60 threshold which suggests that convergence validity is achieved (Hair et al., 2006). The only loading below the threshold was very close at .59. Three-factor solutions were suggested in all cases, with all of the eignenvalues above 1 and a high level of variance explained (>70\%), demonstrating support for discriminant validity in all cases. Inspection of scree plot diagrams provided further confirmation of the suggested three-factor solutions. In addition to factor analysis, the Cronbach Alpha scores for each of the variables were calculated to assess their overall reliability as measures (see Appendix 2). These values ranged from 0.85 to 0.95 indicating a high level of measurement reliability (Hair et al., 2006). Overall, this analysis confirms that the items comprising each of the variables are valid and reliable measures of their overall construct. As a result, they are suitable for further testing through multiple regression analysis.

\section{Data analysis}

Multivariate Ordinary Least Square (OLS) regression analysis is used to test the hypotheses (Hair et al., 2006; Greene, 2011). Prior to analysis, a series of residual diagnostics tests, univariate and graphical 
analysis were used to assess the normality, linearity and homoscedasticity of the data (Hair et al., 2006). These tests indicate that the assumptions for OLS regression are met by the data (Field, 2009; Greene, 2011). Multicollinearity was assessed for through inspection of correlation coefficients as well as the Variance Inflation Factor (VIF) scores which both suggest that multicollinearity is not a concern for the data.

\subsection{Control variables}

Eight control variables are used to control for the following organisational characteristics: plant size (i.e. the natural logarithm of the number of employees); firm age (i.e. age of the firm in year groupings); exporter (i.e. a dichotomous variable indicating if the firm exports their products); independent business unit (i.e. a dichotomous variable indicating whether the firm is independent or part of a larger parent firm); and four industry variables, namely, processed food, beverage, meat and dairy (i.e. dichotomous variables indicating the sub-industry group from which the firm derives based on four-digit SIC codes).

Pairwise correlations for all of the independent and dependent variables are included in Table 1 along with the means and standard deviations for the variables. All of the correlations are below the recommended cut off level of 0.80 (Hair et al., 2006; Tabachnick and Fidell, 2007; Pallant, 2010), however, some of the high correlations did cause some concern regarding multicollinearity. In order to investigate this further the Variance Inflation Factor (VIF) scores were examined. The highest VIF score of 2.73 for the variable energy reduction, was well below the 10.0 threshold suggesting that multicollinearity does not pose a problem in the interpretation of results. Environmental proactivity generated significant correlations with all of the environmental practice variables in the model $(\mathrm{p}<$ 0.01). This provides some preliminary evidence for the hypothesised relationships among these variables. There are also a number of significant correlations among the environmental practice and performance variables again providing some support for the hypothesised relationships among these variables. 
Table 1- Bivariate correlations

\begin{tabular}{|c|c|c|c|c|c|c|c|c|c|c|c|c|c|c|c|c|c|}
\hline No. & Variable & Mean & S.D & 1 & 2 & 3 & 4 & 5 & 6 & 7 & 8 & 9 & 10 & 11 & 12 & 13 & 14 \\
\hline & Control Variables & & & & & & & & & & & & & & & & \\
\hline 1 & Firm Size & 4.71 & 1.22 & & & & & & & & & & & & & & \\
\hline 2 & Firm Age & 3.64 & .09 & $.23 * *$ & & & & & & & & & & & & & \\
\hline 3 & Exporter & .69 & .04 & .07 & .15 & & & & & & & & & & & & \\
\hline 4 & Independent Business Unit & .54 & .50 & -.09 & -.09 & -.01 & & & & & & & & & & & \\
\hline 5 & Processed Food Industry & .21 & .41 & .01 & -.01 & .03 & -.10 & & & & & & & & & & \\
\hline 6 & Beverage Industry & .18 & .39 & .03 & $.31^{* * *}$ & .13 & .05 & $-.24 * *$ & & & & & & & & & \\
\hline 7 & Meat Industry & .17 & .38 & $-.20 *$ & -.13 & .05 & .10 & $-.24 * *$ & $-.22 * *$ & & & & & & & & \\
\hline 8 & Dairy Industry & .14 & .35 & .00 & -.02 & .03 & -.06 & $-.21 *$ & $-.19 *$ & $-.19 *$ & & & & & & & \\
\hline 9 & $\begin{array}{l}\text { Independent Variables } \\
\text { Corporate Env Proactivity }\end{array}$ & 4.90 & 1.29 & .15 & -.00 & $.20 *$ & .01 & .11 & -.04 & -.08 & .03 & & & & & & \\
\hline 10 & Energy Reduction & 5.23 & 1.48 & $.28 * *$ & .05 & .10 & -.09 & .09 & .13 & $-.16^{*}$ & -.00 & $.57 * *$ & & & & & \\
\hline 11 & Waste Reduction & 5.63 & 1.19 & $.27 * *$ & .00 & .00 & -.05 & .13 & -.04 & $-.17 *$ & .14 & $.49 * *$ & $.70 * *$ & & & & \\
\hline 12 & Supplier Collaboration & 4.13 & 1.51 & .03 & -.04 & .10 & -.13 & -.02 & -.07 & -.00 & .02 & $.53 * *$ & $.37 * *$ & $.34 * *$ & & & \\
\hline 13 & Customer Collaboration & 3.54 & 1.59 & $.18^{*}$ & -.05 & .05 & -.10 & .05 & -.09 & -.13 & .08 & $.37 * *$ & $.44^{* *}$ & $.37 * *$ & $.46^{* *}$ & & \\
\hline 14 & Environmental Performance & 4.42 & 1.41 & $.33 * *$ & .06 & .08 & -.01 & .09 & .11 & -.12 & .08 & $.50 * *$ & $.65 * *$ & $.60 * *$ & $.33 * *$ & $.39 * *$ & \\
\hline 15 & Cost Performance & 4.42 & .89 & -.01 & $-.26 * *$ & .13 & -.01 & -.01 & .04 & .03 & -.07 & $.24 * *$ & .16 & $.23^{* *}$ & $.28 * *$ & $.20 *$ & $.34 * *$ \\
\hline
\end{tabular}




\subsection{Hypothesis testing}

Results of the first four sets of regression analyses are presented in Table 2. With energy reduction, waste reduction, supplier collaboration and customer collaboration as dependent variables, control variables are entered in the step 1 . To test hypotheses $1 \mathrm{a}, 1 \mathrm{~b}, 2 \mathrm{a}$ and $2 \mathrm{~b}$, environmental proactivity is entered in the step 2. To assess the overall significance of each regression model, attention is paid to the $R^{2}$ and $F$ statistic as well as the coefficients of environmental proactivity.

Table 2 - Environmental proactivity to environmental practices (direct effects)

\begin{tabular}{|c|c|c|c|c|c|c|c|c|}
\hline & \multicolumn{2}{|c|}{$\begin{array}{c}\text { ENERGY } \\
\text { REDUCTION }\end{array}$} & \multicolumn{2}{|c|}{$\begin{array}{c}\text { WASTE } \\
\text { REDUCTION }\end{array}$} & \multicolumn{2}{|c|}{$\begin{array}{c}\text { SUPPLIER } \\
\text { COLLABORATION }\end{array}$} & \multicolumn{2}{|c|}{$\begin{array}{c}\text { CUSTOMER } \\
\text { COLLABORATION }\end{array}$} \\
\hline & STEP 1 & STEP 2 & STEP 1 & STEP 2 & STEP 1 & STEP 2 & STEP 1 & STEP 2 \\
\hline \multicolumn{9}{|l|}{ Control Variables: } \\
\hline Firm Size & $.28 * * *$ & $.20 * *$ & $.27^{* * *}$ & $.21 * *$ & .01 & -.07 & $.17 * *$ & .12 \\
\hline Independent Business Unit & -.06 & -.08 & -.00 & -.02 & -.13 & $-.15^{* *}$ & -.08 & -.09 \\
\hline Exporter & .07 & -.04 & -.02 & -.11 & .12 & .01 & .07 & .00 \\
\hline Process Food Industry & .12 & .07 & .15 & .11 & -.08 & -.13 & .00 & -.03 \\
\hline Beverage Industry & $.17 *$ & $.20 * *$ & .04 & .06 & -.10 & -.08 & -.08 & -.07 \\
\hline Meat Industry & -.04 & -.01 & -.05 & 0.02 & -.04 & -.01 & -.11 & -.09 \\
\hline Dairy Industry & .04 & .02 & $.16^{*}$ & $.15^{*}$ & -.04 & -.05 & .04 & .03 \\
\hline Firm Age & -.09 & -.06 & -.08 & -.05 & -.04 & -.01 & -.10 & -.08 \\
\hline \multicolumn{9}{|l|}{ Direct Effects: } \\
\hline Environmental Proactivity & & $.55^{* * *}$ & & $.46 * * *$ & & $.55^{* * *}$ & & $.34 * * *$ \\
\hline (Constant) & $3.87 * * *$ & $1.38 * *$ & $4.55^{* * *}$ & $2.85 * * *$ & $4.43 * * *$ & $1.89 * *$ & $3.13^{* * *}$ & $1.45 *$ \\
\hline$\Delta \mathrm{R}^{2}$ & .13 & .27 & .12 & .20 & .04 & .27 & .07 & .11 \\
\hline$\Delta \mathrm{F}$ & $2.54 * *$ & $\begin{array}{l}63.46^{* *} \\
*\end{array}$ & $2.41 * *$ & $\begin{array}{l}40.38 * * \\
*\end{array}$ & .72 & $\begin{array}{l}55.20 * * \\
*\end{array}$ & 1.35 & $18.25 * * *$ \\
\hline Overall $\mathrm{R}^{2}$ & .13 & .40 & .12 & .32 & .04 & .31 & .07 & .18 \\
\hline Adjusted $\mathrm{R}^{2}$ & .08 & .36 & .07 & .28 & -.02 & .26 & .02 & .13 \\
\hline Overall model F & $2.54^{* *}$ & $\begin{array}{l}10.32 * * \\
*\end{array}$ & $2.41 * *$ & $7.23 * * *$ & .72 & $7.02 * * *$ & 1.35 & $3.37 * * *$ \\
\hline $\mathrm{N}$ & 149 & 149 & 149 & 149 & 149 & 149 & 149 & 149 \\
\hline
\end{tabular}

\subsubsection{Pollution prevention models}

The results in step 1 of the energy reduction model show that the control variables together explain 13\% of the variance in energy reduction practices. Firm size and beverage industry both have a statistically significant effect on energy reduction at the ninety-nine percent level $(\mathrm{p}<0.001)$ and ninety percent level $(\mathrm{p}<0.10)$ respectively. The addition of environmental proactivity as a predictor in the second step explains a significant amount of additional variance (change in $R^{2}=27 \%$; the change in F statistic is 63.46, $\mathrm{p}<0.001$ ). The effect of environmental proactivity on energy reduction is positive and highly 
significant $(\beta=0.55, \mathrm{p}<0.001)$. The overall $R^{2}$ indicating the variance explained by the control variables and environmental proactivity is $40 \%$; adjusted for the number of parameters estimated, the $R^{2}$ is $36 \%$, and the full model is statistically significant $(\mathrm{F}=10.32, \mathrm{p}<0.001)$. The results in step 1 of the waste reduction model indicate that the control variables explain $12 \%$ of the variance in waste reduction practices. Within this model firm size and dairy industry both have a statistically significant effect on waste reduction at the ninety-nine percent level $(\mathrm{p}<0.001)$ and ninety percent level $(\mathrm{p}<0.10)$ respectively. The results for step two of the model indicate that environmental proactivity explains a significant amount of additional variance (change in $R^{2}=20 \%$; the change in F statistic is $40.38, \mathrm{p}<$ 0.001). The effect of environmental proactivity on energy reduction is positive and highly significant ( $\beta=0.46, \mathrm{p}<0.001$ ). The overall $R^{2}$ indicating the variance explained by the all of the independent variables is $32 \%$; adjusted for the number of parameters estimated, the $R^{2}$ is $28 \%$, and the full model is statistically significant $(\mathrm{F}=7.23, \mathrm{p}<0.001)$.

These results provide strong support for hypotheses 1a and 1b and confirm the suggested link between an environmentally proactive orientation and the implementation of practices related to pollution prevention. This supports an implicit assumption of the NRBV that proactive engagement with the natural environment can be expressed through a pollution prevention approach (Hart, 1995; Hart and Dowell, 2011). Further, it builds upon other studies which suggest that environmental proactivity can influence the development of internal environmental practices (Montabon et al., 2007; Lopez-Gamero et al., 2009; Akin-Ates et al., 2012). Definitions of pollution prevention imply a set of internal practices seeking to reduce environmental impacts within the production process (Michalisin and Stinchfield, 2010; Thoumy and Vachon, 2012; Hoque and Clarke, 2013). Internal processes are a logical starting point for firms seeking to proactively engage with the natural environment as they can identify areas for improvement within their own operations (Hart, 1995). Following this, they can start to work with key stakeholders to identify areas for improvement within their supply chain (Hart and Dowell, 2011). 


\subsubsection{Process stewardship models}

The last two models outlined in Table 2 include the process stewardship practice variables of supplier collaboration and customer collaboration. Firstly, the model where supplier collaboration constitutes the dependent variable indicates that the control variables jointly explain $4 \%$ of its variance in step one. However, there appear to be no statistically significant relationships among these controls and the dependent variable. At step two of the model, the addition of environmental proactivity as a predictor presents a significant increase in the amount of variance explained (change in $R^{2}=27 \%$; the change in F statistic is 55.20, $\mathrm{p}<0.001$ ). The influence of environmental proactivity on supplier collaboration is positive and highly significant $(\beta=0.55, \mathrm{p}<0.001)$. The overall $R^{2}$ indicating the variance explained by the all of the independent variables is $31 \%$; adjusted for the number of parameters estimated, the $R^{2}$ is $26 \%$, and the full model is statistically significant $(\mathrm{F}=7.03, \mathrm{p}<0.001)$.

The results for step one of the customer collaboration model indicate that the control variables jointly explain $7 \%$ of the variance in the dependent variable. Of these control variables only firm size appears to have a statistically significant impact $(\mathrm{p}<0.05)$. The addition of environmental proactivity as a predictor of customer collaboration results in a significant increase in the amount of variance explained (change in $R^{2}=11 \%$; the change in $\mathrm{F}$ statistic is 18.25, $\mathrm{p}<0.001$ ). The effect of environmental proactivity on customer collaboration is positive and highly significant $(\beta=0.34, p<0.001)$. The overall $R^{2}$ indicating the variance explained by the all of the independent variables is $18 \%$; adjusted for the number of parameters estimated, the $R^{2}$ is $13 \%$, and the full model is statistically significant $(\mathrm{F}=3.37$, $\mathrm{p}<0.001)$

Again, these results provide strong support for hypotheses $2 \mathrm{a}$ and $2 \mathrm{~b}$, confirming the link between environmental proactivity and process stewardship. Consistent with the NRBV's suggested links between proactivity and process stewardship, these findings support the extension of environmental practices to the supply chain level within proactive firms (Hart and Dowell, 2011). This suggests that firms expressing a commitment to the environment through a proactive orientation, are considering not 
only the environmental impact of their own internal practices but also the impact of practices within their supply chain. These efforts are being expressed through collaboration with both suppliers and customers. Environmental collaboration reflects engagement with key stakeholders (suppliers and customers) in response to environmental concerns, a fundamental aspect of a stewardship approach (Vachon and Klassen, 2008; Hart and Dowell, 2011). Bowen et al. (2001) identified a proactive orientation as an important antecedent to environmental supply management. Consistent with this, our findings generate further support for a link between pro-activity and environmental practices with suppliers. Moreover, our results extend this further by confirming a link between pro-activity and customer environmental practices. This indicates that proactive firms are expressing their commitment to the environment through practices both upstream and downstream in the supply chain. With limited research on drivers of supply chain collaboration to date (Bowen et al., 2001; de Leeuw and Fransoo, 2009), these findings develop a case for a proactive orientation being an important antecedent to collaborative activities at the supply chain level.

It is of interest to note that the relationship between environmental proactivity and supplier collaboration appears to be stronger than the relationship between environmental proactivity and customer collaboration. This might be due to the increasing pressure and accountability being placed on lead firms to manage the environmental impact of their supply chains (Rao and Holt, 2005; Hoejmose et al., 2013). By definition, proactivity is indicative of a preventative approach that seeks to target problems at the source. The inputs to the process come from upstream in the supply chain. If environmental concerns are not addressed at this stage, their impact may be carried throughout the supply network. Thus, it is not surprising that proactive firms would target and address environmental concerns with suppliers as a key component of their stewardship approach. Although assessing different factors in relation to environmental collaboration, Vachon and Klassen (2008) identify stronger relationships for supplier collaboration than customer collaboration. Our study is consistent with this and may suggest that collaboration with suppliers is a more prominent practice than collaboration with customers. 
The results for the second set of regression models are displayed in Table 3. In these models, environmental performance and cost performance constitute the respective dependent variables.

Table 3 Environmental practices to organisational performance: Direct effects.

\begin{tabular}{|c|c|c|c|c|}
\hline & \multicolumn{2}{|c|}{$\begin{array}{l}\text { ENVIRONMENTAL } \\
\text { PERFORMANCE }\end{array}$} & \multicolumn{2}{|c|}{$\begin{array}{c}\text { COST } \\
\text { PERFORMANCE }\end{array}$} \\
\hline & STEP 1 & STEP 2 & STEP 1 & STEP 2 \\
\hline \multicolumn{5}{|l|}{ Control Variables: } \\
\hline Firm Size & $.35^{* * *}$ & $.18^{* *}$ & .05 & .01 \\
\hline Independent Business unit & .03 & .07 & -.04 & -.02 \\
\hline Exporter & .03 & -.01 & $.16^{* *}$ & $.15^{*}$ \\
\hline Process Food Industry & $.18^{* *}$ & .11 & -.01 & -.01 \\
\hline Beverage Industry & $.21^{* *}$ & $.16^{* *}$ & .10 & .14 \\
\hline Meat industry & .06 & .10 & .00 & .02 \\
\hline Dairy Industry & $.16^{*}$ & .11 & -.70 & -.10 \\
\hline Firm Age & -.08 & -.02 & $-.33^{* * *}$ & $-.31^{* * *}$ \\
\hline
\end{tabular}

Direct Effects:

Energy Reduction Practices

Waste Reduction Practices

Supplier Environmental Collaboration

Customer Environmental Collaboration

$\begin{array}{ll}.35^{* * *} & -.14 \\ .24^{* *} & .25^{* *} \\ .10^{*} & .19^{* *} \\ .09 & .07\end{array}$

(Constant)

$2.42 * * * \quad-.81$

$5.10 * * * \quad 3.93 * * *$

$\Delta \mathrm{R}^{2}$

$\Delta \mathrm{F}$

Overall $\mathrm{R}^{2}$

Adjusted $\mathrm{R}^{2}$

$\begin{array}{lllll}\text { Overall model } \mathrm{F} & 3.23^{* *} & 12.06^{* * *} & 2.28^{* *} & 3.09^{* * *} \\ \mathrm{~N} & 149 & 149 & 149 & 149\end{array}$

.16

.81

5.10

.10

$3.32 * * \quad 24.99 * * * \quad 2.28 * * \quad 4.27 * *$

$\begin{array}{llll}.16 & .52 & .12 & .21\end{array}$

Note: ${ }^{* * *} \mathrm{p}<0.001,{ }^{* *} \mathrm{p}<.05,{ }^{*} \mathrm{p}<.10$ (one-tailed tests for hypotheses; two-tailed tests for controls). Standardized regression coefficients are shown.

\subsubsection{Pollution prevention and organisational performance}

Results for the hypothesised links between pollution prevention practices and organisational performance are presented across the two models outlined in Table 3. Control variables are included at step 1 of each model and the environmental practice variables at step 2. A significant increase in the variance explained is evident upon the inclusion of the environmental practice variables in each model (environmental performance model: change in $R^{2}=36 \%$; the change in F statistic is 12.06, $\mathrm{p}<0.001$; cost performance model: change in $R^{2}=10 \%$; the change in F statistic is 4.27, $\mathrm{p}<0.05$ ). Both pollution prevention practices appear to exert a positive influence on environmental performance (energy reduction: $\beta=0.35, \mathrm{p}<0.001$, waste reduction: $\beta=0.24, \mathrm{p}<0.05$ ). These results provide strong support for hypotheses 3a and 3b. When cost performance constitutes the dependent variable, significant results 
are noted in the case of waste reduction $(\beta=0.25, \mathrm{p}<0.05)$, but not energy reduction. This generates support for hypothesis 4b, however, hypothesis 4a remains unsupported.

A strong link between pollution prevention practices and environmental performance is evident from the results. This suggests that the implementation of these practices may lead to improvements in environmental performance. Considering the pre-planned preventative efforts comprising a pollution prevention approach, firms would expect to see an improvement in the environmental impact of their processes. Our findings are consistent with other studies that note a link between internal environmental practices and improved environmental performance (Sroufe, 2003; Zhu and Sarkis, 2004; Rao and Holt, 2005). Further, they confirm that the development of a pollution prevention approach, as outlined in the NRBV, can lead to enhanced environmental performance (Hart, 1995; Hart and Dowell, 2011). This is an important consideration as firms who proactively engage with the natural environment through pollution prevention, do so with the objective to improve their environmental performance.

Regarding the relationship between pollution prevention and cost performance, mixed support is provided by the results. There is strong support for a link between waste reduction and cost performance but no support for this link in the case of energy reduction. A number of studies have found support for a link between internal environmental practices, similar to those comprising a pollution prevention approach, and dimensions of operational performance such as cost (Klassen and McLaughlin, 1996; Rao and Holt, 2005; Griffith and Bhutto, 2009; Schoenherr, 2012). However, these studies often indicate that some practices may be linked to all dimensions of operational performance while others may be linked to some or none of these dimensions (Vachon and Klassen, 2008). Our findings seem to further reflect that this is the case. This may be due to the level of investment required for certain environmental practices within the UK food industry. For example, the practices used for waste reduction may be more straightforward or require less investment than those used for energy reduction. Energy reduction may require investment in more efficient technologies which would require substantial investment that may offset potential cost savings. The complex and expansive range of environmental practices adopted within the food industry can also lead to variations in performance 
outcomes (Pullman et al., 2009). Thus, it might be useful for future studies to identify and assess more specific practices within this context.

\subsubsection{Process stewardship and organisational performance}

The environmental performance model provides support for a significant positive relationship with supplier collaboration $(\beta=0.10, p<0.10)$, consistent with hypothesis 4a. However, customer collaboration does not appear to have any statistically significant impact on environmental performance. This model is deemed to be statistically significant $\left(R^{2}=52 \%\right.$; $\left.\mathrm{F}=12.06, \mathrm{p}<0.001\right)$. Thus hypothesis $4 \mathrm{a}$ is accepted and hypothesis $4 \mathrm{~b}$ rejected in light of the results. The cost performance model indicates a significant positive relationship with supplier collaboration $(\beta=0.19, \mathrm{p}<0.05)$, consistent with hypothesis 4c. Again, no such support is provided in the case of customer collaboration. The significance of the overall model $\left(R^{2}=21 \% ; \mathrm{F}=3.09, \mathrm{p}<0.001\right)$ leads to acceptance of hypothesis $4 \mathrm{c}$ and rejection of hypothesis $4 \mathrm{~d}$.

Overall, the support for a link between process stewardship and environmental and cost performance is mixed. The results indicate a positive significant relationship with both dimensions of performance in the case of supplier collaboration, but no support for any links with performance in the case of customer collaboration. This suggests that working with suppliers to tackle environmental concerns may enhance the performance of the lead firm, whilst working with customers may not lead to the same improvements within the UK food industry. This is an interesting finding in light of other studies that note positive and significant results in relation to both aspects of environmental collaboration (Vachon and Klassen, 2008; Wiengarten et al., 2013; Blome et al., 2014). For example, Vachon and Klassen (2008) present strong support for both supplier and customer collaboration to influence environmental performance within manufacturing firms. Further, a number of other studies present strong support for environmental supply chain practices to generate improved environmental performance (Zhu and Sarkis, 2004; Rao and Holt, 2005; Blome et al., 2014). One potential explanation for this finding is the substantial role played by retail customers within the UK food industry. As a result of their dominant market position, 
retailers are able to ensure that collaborative environmental initiatives are focussed and aligned with their environmental goals.

Regarding cost performance, the supported relationship with supplier collaboration is consistent with other studies that identify the potential for environmental practices upstream in the supply chain to influence cost performance (Rao and Holt, 2005; Vachon and Klassen, 2008; Paulraj, 2011). While these studies assess relationships in the broader context of manufacturing, our study builds upon them by providing further support in the narrower context of the UK food industry. This finding also supports the arguments of the NRBV in relation to a stewardship approach and the generation of competitive advantage (Hart, 1995; Hart and Dowell, 2011). The customer collaboration finding was not as expected and suggests that collaborative environmental efforts with customers may not generate improved cost performance. This suggests that certain components of a process stewardship approach may lead to enhanced cost performance whilst others may not. While unexpected, this finding is consistent with some other studies in the extant literature (Zhu et al., 2007; Green et al., 2012). For example, Zhu et al., (2007) find no support for links between customer collaboration and environmental or cost performance. More recently, Green et al., (2012) find that customer collaboration is positively linked to environmental performance but not to economic performance. Within the extant literature, the link between external environmental practices such as customer collaboration and performance appears to be more ambiguous than that between internal environmental practices and organisational performance (De Giovanni, 2012). Thus, it is not surprising that the hypotheses relating to external (supply chain) practices did not obtain the same level of support as those relating to the internal practices.

Some studies suggest that relational resources are a key element in obtaining potential performance outcomes from external environmental collaboration with customers and suppliers (Vachon and Klassen, 2008; Blome et al., 2014). Consideration of relational factors might provide an explanation for the ambiguous results regarding environmental collaboration and organisational performance. Namely, within the context of the UK food industry, managers are able to build and sustain collaborative relationships that benefit organisational performance with suppliers, whereas collaborative 
relationships that generate a positive impact on organisational performance are more difficult to form with retail customers. Integration and alignment of environmental objectives across both parties is an important aspect of collaboration (Vachon et al., 2009). This may be easier to achieve in the case of suppliers than larger retail customers, particularly where the lead firm has some influence in the relationship (De Leeuw and Fransoo, 2009). Retailer domination is a prominent characteristic of the UK food industry (Robson and Rawnsley, 2001). Retailers effectively are the customers of food processing firms and therefore are likely to be the dominant party in collaborative activities (Mena et al., 2014). As a result, opportunities to improve organisational performance identified by the food processing firms may not always be achieved.

Figure 2 outlines the supported hypotheses from the framework.

Figure 2 Research framework with supported hypotheses

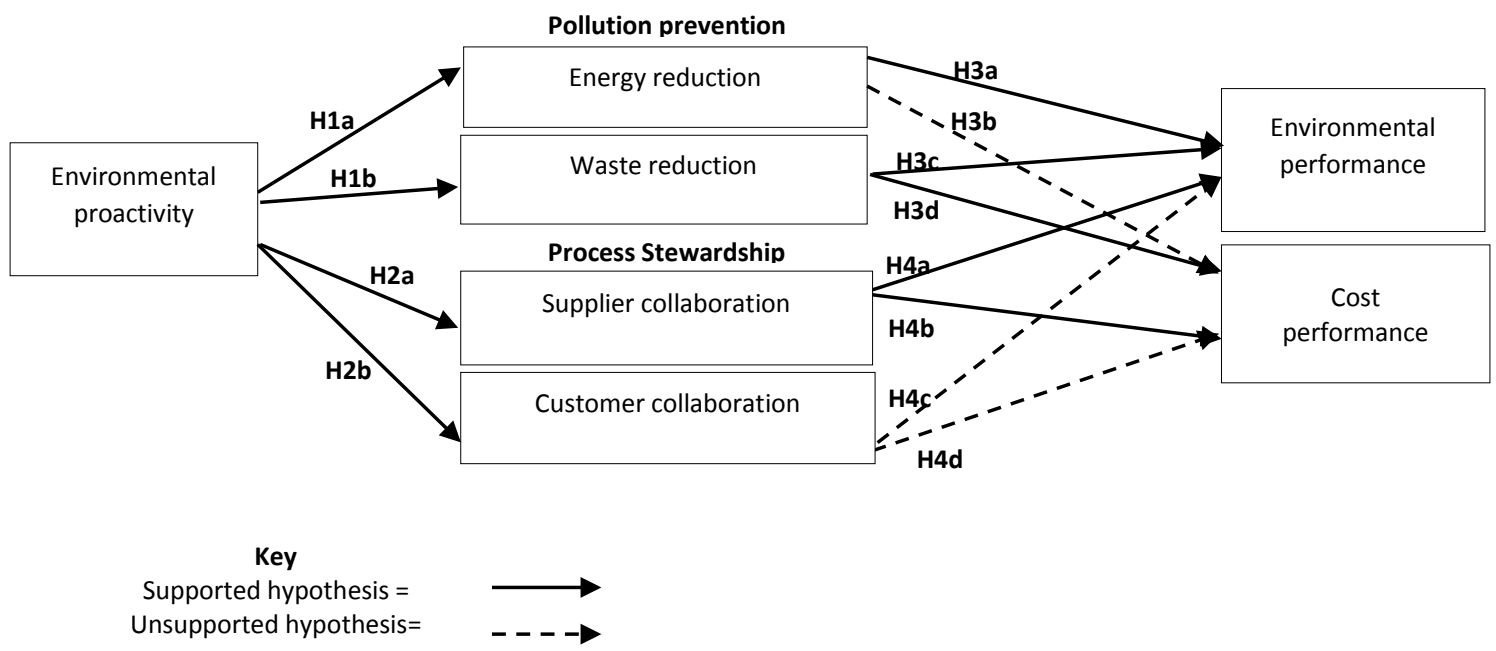

It is interesting to note that a number of the control variables are significant across the models. In particular firm size is positively linked to a number of the environmental practice variables, namely, energy reduction ( $p<0.001)$, waste reduction $(p<0.001)$ and customer collaboration $(p<0.05)$. This is not surprising and fits in well with other studies that highlight the important influence of firm size in the development of environmental practices (Chan, 2005; Gonzalez-Benito and Gonzalez-Benito, 2005; 
Darnall et al., 2008; 2010). A potential explanation for this is that larger firms possess more financial and human capital for the upfront investments required for the implementation of new environmental practices. A significant positive link is also noted between firm size and environmental performance ( $\mathrm{p}$ $<0.001)$. This suggests that larger firms may be more likely to benefit from improved environmental performance. A potential reason for this might be that their operations are larger generating more room for potential improvements to be made.

\section{Conclusions}

This study has analysed the influence of a pro-active orientation on environmental practices and subsequently, the influence of these environmental practices on environmental and cost performance. The findings from this study fit with and build upon the extensive research base on approaches to and performance outcomes of environmental management (Akin-Ates et al., 2012; De Burgos-Jiminez et al., 2014). Two sets of environmental practices related to pollution prevention and process stewardship are considered at the heart of the framework. Our results indicate that within the context of the UK food industry, environmental proactivity is an important antecedent to both pollution prevention and process stewardship. Results for the organisational performance outcomes derived from environmental practices are mixed. Strong support for the link between environmental practices and environmental performance is provided along with some support for the link with cost performance. These findings shed new light on the relationships between environmental approach, practices and performance by integrating these prominent areas of research and assessing their interrelationships. Taken together, the findings provide broad support for the propositions of the NRBV (Hart, 1995; Hart and Dowell, 2011). The key argument that pro-active environmental efforts can result in performance improvements has been empirically supported, although not unequivocally.

\subsection{Research contributions}




\subsubsection{Theoretical contributions}

This study adopts a novel perspective to assess the link between environmental proactivity and environmental practices. Rather than viewing environmental proactivity as a component of certain practices or systems as in other studies (e.g. Buysse and Verbeke, 2003; Montabon et al., 2007; LopezGamero et al., 2009; Zailani et al., 2012), this study considers environmental proactivity as a standalone concept with the potential to influence the environmental practices adopted by firms. The merit of assessing proactivity as an independent construct has been noted in recent studies (Akin-Ates et al., 2012; De Burgos-Jiminez et al., 2014), yet we are not aware of many studies that assess the direct influence of a pro-active environmental orientation on environmental practices being implemented. This is an important consideration because exploring the extent to which a pro-active orientation is expressed through environmental practices sheds light on the relationship between what firms think they do and what they actually do in practice: between espoused and actual practices. In other words, firms may claim to be 'pro-active' with regard to their environmental efforts, yet a lack of practical attention to environmental concerns may compromise this claim.

A number of studies suggest a link between environmental proactivity and environmental practices (Hart, 1995; Russo and Fouts, 1997; Buysse and Verbeke, 2003; Murillo-Luna et al., 2011). This study goes further and empirically tests this link by developing a framework comprising two sets of practices outlined within the NRBV framework, namely, pollution prevention and process stewardship (Hart and Dowell, 2011; Wong et al., 2012). As far as we are aware no other study empirically tests the links between environmental proactivity, pollution prevention and process stewardship. These practices, at the heart of the NRBV framework are suggested to be an expression of a pro-active commitment to the environment (Hart, 1995), yet, direct links between a pro-active orientation, pollution prevention and process stewardship do not appear to be established within the literature to date.

Further, this study generates novel insights on the relationship between environmental practices and organisational performance. Consideration of the links between pollution prevention, process stewardship and organisational performance enables empirical testing of the NRBV's proposition that 
these practices can enhance performance and lead to competitive advantage. While a number of studies assess links between various environmental practices and organisational performance, few assess practices that are specifically related to the NRBV framework. Investigation of the performance outcomes from pollution prevention and process stewardship enables empirical confirmation of the propositions of the NRBV, thus aiding its development as a theoretical framework.

In considering both antecedents and outcomes of pollution prevention and process stewardship, this study provides a comprehensive investigation of the NRBV and its propositions. To date, the majority of studies have looked at different aspects of this framework in a somewhat piecemeal manner (Chan, 2005). As far as we are aware, this study provides preliminary empirical support for the links between proactivity, pollution prevention and process stewardship. Furthermore, the results contribute to the ongoing debate on the benefits of environmental management (Green et al., 2012; De Burgos-Jiminez et al., 2014). The majority of studies investigating the link between environmental management and organisational performance do not consider strategic orientation in relation to the practices they assess (Lopez-Gamero et al., 2009; Wong et al., 2012). In considering links between a pro-active environmental orientation, environmental practices and organisational performance, this study demonstrates that a pro-active environmental orientation can translate into environmental practices that enhance organisational performance to some degree.

\subsubsection{Managerial implications}

Our findings generate interesting insights for management and supply chain practitioners. By conducting an empirical study, we establish evidence beyond the anecdotal, that firms expressing a proactive orientation through pollution prevention and process stewardship can obtain benefits in the form of improved environmental and cost performance. Firstly, our framework provides some guidance to managers on how a pro-active environmental orientation may translate into specific environmental practices within the context of the UK food industry. This illustrates the types of environmental activities being conducted by manufacturing firms within this context and enables others to follow suit. Secondly, the findings provide support for a link between environmental practices and environmental 
performance. This should enable managers who want to improve their environmental performance to take note of specific environmental practices that might enable them to do this. Thirdly, there is some support for the link between environmental practices and cost performance which enables managers to see that improvements beyond the environmental dimension are also possible in some cases. This is a very important insight for managers who are likely to only consider pro-active environmental engagement if there is some kind of reward in it for them (Figge and Hahn, 2012).

\subsection{Limitations and future research directions}

This study contains some limitations that should be highlighted. First, the lack of established measures for a number of the concepts meant that new measures had to be developed. While these have met the requirements of validity and reliability, previously tested and used measures are preferable. Second, the list of environmental practices included within the model is not extensive. There are a number of other environmental practices that might have been considered and a decision was made to select this group of practices based on their prominence in the literature as well as their relation to the NRBV framework. Third, the time frame used to measure the constructs was two years. While this is consistent with previous studies that suggest a one to two year time lag between implementation of environmental practices and certain performance outcomes (Hart and Ahuja, 1996), it excludes the potential to consider relationships over a longer time period. Furthermore, there was no consideration of how long the environmental practices had been implemented. It might have been useful to have this information as it would have enabled consideration of whether the environmental practices that had been implemented for a longer time had more of an impact on organisational performance.

With regard to future research directions, there is room for studies to consider other factors that might influence the relationship between environmental practices and organisational performance. First, one potential area for future research is to investigate the organisational antecedents that determine which environmental practices are integrated within the firm and across its supply chain (Ronnenberg et al., 2011). Second, it would be valuable for future studies to explore the level at which certain environmental practices are integrated within firms as well as the processes used to enable deeper 
environmental integration. For example, Sarkis et al., (2010) consider the potential for environmental training programmes to enhance the implementation of certain environmental practices. There is room for future studies to build upon this further and consider other organisational factors that may enable a deeper level of environmental integration. Third, consideration of the extent to which environmental practices are aligned with other operational goals, such as cost performance, would provide another potential avenue for future research. For example, are environmental efforts aligned with traditional operational goals such as cost reduction or are they implemented in a more isolated, disconnected manner? This is something that future studies should consider as it might provide insight into the relationship between environmental practices and organisational performance.

\section{Acknowledgement}

The authors acknowledge financial support from the Department of Education and Learning (DEL) In Northern Ireland and the Assured Safe and Traceable Food (ASSET) Research Project at Queen's University Belfast. 


\section{Appendices}

Appendix 1a - Factor loadings (Group 1)

\begin{tabular}{|c|c|c|c|}
\hline Items & $\mathbf{1}$ & 2 & 3 \\
\hline Waste Reduction & & & \\
\hline We monitor and assess levels of waste to see where improvements can be made & .87 & & \\
\hline We have communicated with employees regarding waste reduction & .86 & & \\
\hline We are striving to eliminate unnecessary waste from our production process & .83 & & \\
\hline We train our employees to effectively reduce waste & .82 & & \\
\hline We recycle waste materials where possible & .68 & & \\
\hline $\begin{array}{l}\text { We have sought help from third parties in dealing with waste reduction } \\
\text { Environmental Proactivity }\end{array}$ & .59 & & \\
\hline Our management gives high priority to environmental issues & & .86 & \\
\hline The top managers in our business unit give environmental issues a high priority & & .85 & \\
\hline We lead our industry on environmental issues & & 82 & \\
\hline $\begin{array}{l}\text { We always attempt to go beyond basic compliance with laws and regulations on } \\
\text { environmental issues }\end{array}$ & & .77 & \\
\hline We effectively manage the environmental risks which affect our business & & .64 & \\
\hline Supplier Environmental Collaboration & & & \\
\hline We cooperate with our suppliers to improve their waste reduction initiatives & & & .93 \\
\hline We cooperate with our suppliers for cleaner production & & & .89 \\
\hline We encourage our suppliers to be more efficient in cutting back waste & & & .83 \\
\hline We cooperate with our suppliers to achieve environmental objectives & & & .78 \\
\hline $\begin{array}{r}\text { Variance Explained } \\
\text { Eigenvalues }\end{array}$ & $\begin{array}{c}45.91 \\
6.89\end{array}$ & $\begin{array}{r}16.38 \\
2.46\end{array}$ & $\begin{array}{c}10.53 \\
1.58\end{array}$ \\
\hline
\end{tabular}

\section{Appendix 1b - Factor loadings (Group 2)}

\begin{tabular}{|c|c|c|c|}
\hline Items & 1 & 2 & 3 \\
\hline $\begin{array}{l}\text { Energy Reduction } \\
\text { We monitor energy use to see where improvements can be made } \\
\text { We have assessed operations to identify areas of energy inefficiency } \\
\text { We have communicated with employees regarding energy consumption } \\
\text { Our employees have been trained in reducing energy consumption } \\
\text { We have taken steps to reduce use of excess energy } \\
\text { Environmental Performance } \\
\text { Reduced raw materials usage } \\
\text { Reduced carbon dioxide emissions } \\
\text { Decrease of consumption of hazardous/harmful/toxic materials } \\
\text { Reduced water use by factories } \\
\text { Reduced energy usage } \\
\text { Cost Performance } \\
\text { Total product costs } \\
\text { Production costs } \\
\text { Transportation costs } \\
\text { Material innut } 0 \text { sts }\end{array}$ & $\begin{array}{l}.82 \\
.87 \\
.85 \\
.82 \\
.85\end{array}$ & $\begin{array}{l}.78 \\
.72 \\
.71 \\
.69 \\
.64\end{array}$ & $\begin{array}{l}.90 \\
.89 \\
.82 \\
68\end{array}$ \\
\hline $\begin{array}{r}\text { Variance Explained } \\
\text { Eigenvalues }\end{array}$ & $\begin{array}{c}44.30 \\
6.20\end{array}$ & $\begin{array}{c}19.82 \\
2.77\end{array}$ & $\begin{array}{c}.68 \\
8.39 \\
1.18\end{array}$ \\
\hline
\end{tabular}

\section{Appendix 1c - Factor loadings (Group 3)}

\begin{tabular}{l|c|c|c}
\hline \multicolumn{1}{c|}{ Items } & $\mathbf{1}$ & $\mathbf{2}$ & $\mathbf{3}$ \\
\hline $\begin{array}{l}\text { Customer Collaboration } \\
\text { Working together to reduce the environmental impact of our activities }\end{array}$ & .90 & & \\
$\begin{array}{l}\text { Making joint decisions about ways to reduce the overall environmental impact of our } \\
\text { products }\end{array}$ & .89 & & \\
\hline
\end{tabular}




\begin{tabular}{|c|c|c|c|}
\hline Conducting joint planning to anticipate and resolve environmental-related problems & .88 & & \\
\hline $\begin{array}{l}\text { Developing a mutual understanding of responsibilities regarding environmental } \\
\text { performance }\end{array}$ & .87 & & \\
\hline Achieving environmental goals collectively & .84 & & \\
\hline Environmental Integration & & & \\
\hline $\begin{array}{l}\text { We have frequent face-to-face communication about environmental issues across } \\
\text { departments }\end{array}$ & & .91 & \\
\hline $\begin{array}{l}\text { We actively share knowledge across internal functions in order to minimise our } \\
\text { plant's environmental impact }\end{array}$ & & .88 & \\
\hline $\begin{array}{l}\text { We actively cooperate across internal functions in order to minimise our plant's } \\
\text { environmental impact }\end{array}$ & & .86 & \\
\hline Quality Performance & & & \\
\hline Significantly reduced the number of product defects & & & .94 \\
\hline Significantly reduced the number of product recalls & & & .94 \\
\hline Improved overall product quality & & & .91 \\
\hline $\begin{array}{r}\text { Variance Explained } \\
\text { Eigenvalues }\end{array}$ & $\begin{array}{c}50.90 \\
5.60\end{array}$ & $\begin{array}{c}23.33 \\
2.57\end{array}$ & $\begin{array}{c}11.79 \\
1.30\end{array}$ \\
\hline
\end{tabular}

Appendix 2 Reliability analysis

\begin{tabular}{|c|c|}
\hline Variable & Cronbach's Alpha \\
\hline Environmental Proactivity & .90 \\
\hline Energy Reduction & .93 \\
\hline Waste Reduction & .89 \\
\hline Supplier Environmental Collaboration & .92 \\
\hline Customer Collaboration & .95 \\
\hline Environmental Performance & .85 \\
\hline Cost Performance & .87 \\
\hline
\end{tabular}

\section{References}

Akin-Ates, M., J. Bloemhof, E. Raaij and F. Wynstra (2012). Proactive environmental strategy in a supply chain context: the mediating role of investments. International Journal of Production Research, 50 (4): 1079-1095.

Armstrong, S. J. and T. S. Overton (1977). Estimating non-response bias in mail surveys. Journal of Marketing Research, 14(August): 396-402.

Bansal, P. (2002). The corporate challenges of sustainable development. Academy of Management Executive, 16(2): 122-131.

Beamon, B. M. (2008). Sustainability and the future of supply chain management. Operations and Supply Chain Management, 1(1): 4-18.

Beske, P., A. Land and S. Seuring. Sustainable supply chain management practices and dynamic capabilities in the food industry: A critical analysis of the literature. International Journal of Production Economics, 152: 131-143.

Blome, C., A. Paulraj and K. Schuetz (2014). Supply chain collaboration and sustainability: a profile deviation analysis. International Journal of Operations and Production Management, 34 (5): 639663.

Bowen, F., P. Cousins, R. Lamming and A. Faruk (2001). The role of supply management capabilities in green supply. Production and Operations Management, 10(2): 174-189.

Buysse, K. and A. Verbeke (2003). Proactive environmental strategies: A stakeholder management perspective. Strategic Management Journal, 24: 453-470.

Cannella, S. and E. Ciancimino (2010). On the bullwhip avoidance phase: supply chain collaboration and order smoothing. International Journal of Production Research, 48(22): 6739-6776.

Cao, M. and Q. Zhang (2011). Supply chain collaboration: Impact on collaborative advantage and firm performance, Journal of Operations Management, 29: 163-180. 
Chan, R. (2005). Does the Natural-Resource-Based view of the firm apply in an emerging economy? A survey of Foreign invested enterprise in China. Journal of Management Studies, 42(3): 625-672.

Christmann, P. (2000). Effects of "best practices" of environmental management on cost advantage: the role of complementary assets. Academy of Management Journal, 43(4): 663-680.

Christopher, M. (2010). Logistics and supply chain management. $4^{\text {th }}$ Edition. Pearson Education.

Dam, L. and B. Petkova (2014). The impact of environmental supply chain sustainability. International Journal of Operations and Production Management, 34 (5): 586-609.

Darnall, N., I. Henriques and P. Sadorsky (2010). Adopting Proactive Environmental Strategy: The influence of stakeholders and firm size. Journal of Management Studies, 47(6): 1072-1094.

Darnall, N., J. G. Jolley and R. Handfield (2008). Environmental management systems and green supply chain management: complements or contradictions. Business Strategy and the Environment, 17(1): 30.

Da Silva, G. and D. De Medeiros (2004). Environmental management in Brazilian firms. Management of Environmental Quality: An International Journal, 15(4): 380-388.

De Burgos-Jiminez, J., D. Vazquez-Brust and J. Plaza-Ubeda (2014). Environmental protection and financial performance: an empirical analysis in Wales, International Journal of Production and Operations Management, 33 (8): 981-1018.

De Giovanni, P. (2012). Do internal and external environmental management contribute to the triple bottom line? International Journal of Production and Operations Management, 32(3): 265-290.

De Leeuw, A. and J. Fransoo (2009). Drivers of close supply chain collaboration: one size fits all? International Journal of Operations and Production Management, 29 (7): 720-739.

Devaraj, S., L. Krajewski and J. Wei (2007). Impact of eBusiness technologies on operational performance: The role of production information integration in the supply chain, Journal of Operations Management, 25 (6): 1199-1216.

Diamantopoulos, A., N. Reynolds and B. Schlegelmich (1994). Pretesting in questionnaire design: The impact of ret characteristics on error detection. Journal of the Market Research Society, 36(4): 295313.

Dias-Sardinha, I. and L. Reijnders (2001). Environmental performance evaluation and sustainability performance evaluation of organisations: an evolutionary framework. Eco-Management and Auditing, 8: 71-79.

Dillman, D. (2007). Mail and Internet Surveys: The Tailored Design Method. New Jersey, John Wiley and Sons Inc.

Drucker, D. (2005). Doing Research: Methods of Inquiry for Conflict Analysis. California, Sage Publications.

Elofson, G. and W. Robinson (2007). Collective customer collaboration impacts on supply-chain performance. International Journal of Production Research, 11(1): 2567-2594.

Etter, J. and T. Perneger (1997). Analysis of non-response bias in a mailed health survey. Journal of Clinical Epidemiology, 50(10): 1123-1128.

Figge, F. and T. Hahn (2012). Is green and profitable sustainable? Assessing the trade-off between economic and environmental aspects, International Journal of Production Economics, 140 (1): 92-102.

Forza, C. (2002). Survey research in operations management: a process-based perspective. International Journal of Operations \& Production Management, 22(2): 152-194.

Fowler, F. J., Jr. (1993). Survey Research Methods. Thousand Oaks, CA, Sage.

Garces-Ayerbe, C., P. Rivera-Torres and J. Murillo-Luna (2012). Stakeholder pressure and environmental proactivity: Moderating effect of competitive advantage expectations. Management Decision, 50 (2): 189-206.

Geffen, C. and S. Rothenberg (2000). Suppliers and environmental innovation: the automotive paint process. International Journal of Operations and Production Management, 20(2): 166-186.

Giminez, C., V. Sierra and J. Rodon (2012). Sustainable operations: Their impact on the triple bottom line. International Journal of Production Economics, 140: 149-159.

Giminez, C. and E. Tachizawa (2012). Extending sustainability to suppliers: a systematic literature review. Supply Chain Management: An International Journal, 17 (5): 531-543.

Goldsby, T. J. and T. P. Stank (2000). World Class Logistics Performance and Environmentally Responsible Logistics Practices. Journal of Business Logistics, 21(2): 187-208.

Gonzalez-Benito, J. and O. Gonzalez-Benito (2005). Environmental proactivity and business performance: an empirical analysis. Omega, The International journal of Management Science, 33: 1-15. 
Greene, W. H. (2011). Econometric Analysis. Pearson Education, Harlow, England.

Green, K. W., P. J. Zelbst, V. Bhadauria and J. Meacham (2012). Do environmental collaboration and monitoring enhance organisational performance? Industrial Management and Data systems, 112(2): 186-205.

Grekova, K., H. Bremmers, J. Trienekens, R. Kemp and S. Omta (2014). Extending environmental management beyond the firm boundaries: An empirical study of Dutch food and beverage firms. International Journal of Production Economics, 152: 174-187.

Griffith, A. and K. Bhutto (2009). Better environmental performance: A framework for integrated management systems (IMS). Management of Environmental Quality: An International Journal, 20(5): 566-580.

Hair, J. F., W. C. Black, B. Babin, R. Anderson and R. Tatham (2006). Multivariate Data Analysis, Pearson Prentice Hall.

Halldorsson, A., H. Kotzab and T. Skjott-Larsen (2009). Supply chain management on the crossroad to sustainability: a blessing or a curse? Logistics Research, 1(2): 83-94.

Hart, S. and G. Dowell (2011). A natural-resource-based view of the firm: Fifteen years after. Journal of Management, 37 (5): 1464-1479.

Hart, S. L. (1997). Beyond greening: strategies for sustainable development. Harvard Business Review, 75(1): 66-76.

Hart, S. and G. Ahuja (1996). Does it pay to be green? Business Strategy and the Environment, 5: 30-37.

Hart, S. (1995). A natural-resource-based view of the firm. Academy of Management Review, 20(4): 9861014.

Henriques, I. and P. Sadorsky (1999). The relationship between environmental commitment and managerial perceptions of stakeholder importance. Academy of Management Journal, 42(1): 87-99.

Hoejmose, S., J. Grosvold and A. Millington (2013). Socially responsible supply chains: power asymmetries and joint dependence. Supply Chain Management: An International Journal, 18 (3): 277-291.

Hofer, C., D. Cantor and J. Dai (2012). The competitive determinants of a firm's environmental management activities: Evidence from US manufacturing industries. Journal of Operations Management, 30: 6984.

Hollos, D., C. Blome, and K. Foerstl (2012). Does sustainable supplier co-operation affect performance? Examining implications for the triple bottom line. International Journal of Production Research, 50 (11): 2968-2986.

Hoque, A. and A. Clarke (2013). Greening of industries in Bangladesh: pollution prevention practices. Journal of Cleaner Production, 51: 47-56.

Humphreys, P., R. McIvor and F. Chan (2003). Using case-based reasoning to evaluate supplier environmental management performance. Expert Systems with Applications, 25: 141-153.

Iwata, H. and K. Okada (2011). How does environmental performance affect financial performance? Evidence from Japanese manufacturing firms, Ecological Economics, 70: 1691-1700.

Jeffers, P. (2010). Embracing sustainability: Information technology and the strategic leveraging of operations in third-party logistics, International Journal of Operations and Production Management, 30 (3): 260-287.

Kaipia, R., I. Dukovska-Popovska and L. Loikkanen (2013). International Journal of Physical Distribution and Logisitics Management, 43 (3): 262-276.

King, A. and M. Lenox (2001). Lean and green? An empirical examination of the relationship between lean production and environmental performance. Production and Operations Management, 10(3): 244.

Klassen, R. and S. Vachon (2003). Collaboration and evaluation in the supply chain: The impact on plantlevel environmental investment. Production and Operations Management, 12 (3): 336-352.

Lopez-Gamero, M., J. Molina-Azorin and E. Claver-Cortes (2009). The whole relationship between environmental variables and firm performance: Competitive advantage and firm resources as mediator variables, Journal of Environmental Management, 90: 3110-3121.

Lo, S. (2014). Effects of supply chain position on the motivation and practices of firms going green. International Journal of Production and Operations Management, 34 (1): 93-114.

Li, D., X. Wang, H. Chan and R. Manzini (2014). Editorial: Sustainable food supply chain management. International Journal of Production Economics, 152: 1-8.

Maloni, M. and M. Brown (2006). Corporate social responsibility in the supply chain: An application in the food industry. Journal of Business Ethics, 68: 35-52. 
Mahalik, N. and A. Nambiar (2010). Trends in food packaging and manufacturing systems and technology. Trends in Food Science and Technology, 21: 117-128.

Mattas, K. and E. Tsakiridou (2010). Shedding fresh light on food industry's role: the recession's aftermath. Trends in Food Science and Technology, 21: 212-216.

Melnyk, S., R. Sroufe and R. Calantone (2003). Assessing the impact of environmental management systems on corporate and environmental performance. Journal of Operations Management, 21: 329-351.

Mena, C., L. Terry, A. Williams and L. Ellram (2014). Causes of waste across multi-tier networks: Cases in the UK food sector. International Journal of Production Economics, 152: 144-158.

Michalisin, M. D. and B. T. Stinchfield (2010). Climate Change Strategies and Firm Performance: An Empirical Investigation of the Natural Resource- Based View of the Firm. Journal of Business Strategies, 27(2): 123-149.

Montabon, F., R. Sroufe and R. Narashimhan (2007). An examination of corporate reporting, environmental management practices and firm performance. Journal of Operations Management, 25: 998-1014.

Munguia, N., A. Zavala and A. Marin (2010). Identifying pollution prevention opportunities in the Mexican auto refining industry. Management of Environmental Quality: An International Journal, 21 (3): 324-335.

Murillo-Luna, J., C. Garces-Ayerbe and P. Riverra-Torres (2011). Barriers to the adoption of proactive environmental strategies. Journal of Cleaner Production, 19: 1417-1425.

Pagell, M. and Z. Wu (2009). Building a more complete theory of sustainable supply chain management using case studies of 10 exemplars. Journal of Supply Chain Management, 45(2): 37-56.

Paulraj, A. (2011). Understanding the relationships between internal resources and capabilities, sustainable supply management and organisational sustainability. Journal of Supply Chain Management,_47(1): 19-37.

Paulraj, A. and P. de Jong (2011). The effect of ISO 14001 certification announcements on stock performance. International Journal of Operations and Production Management. 31 (7): 765-788.

Porter, M. and M. R. Kramer (2006). Strategy and society: The link between competitive advantage and corporate social responsibility. Harvard Business Review: 78-92.

Preuss, L. (2005). Rhetoric and reality of corporate greening: a view from the supply chain management function. Business Strategy and the Environment, 14: 123-139.

Pullman, M., M. Maloni and C. Carter (2009). Food for thought: social versus environmental sustainability practices and performance outcomes. Journal of Supply Chain Management, 45(4): 38-54.

Rao, P. and D. Holt (2005). Do green supply chains lead to competitiveness and economic performance? International Journal of Production and Operations Management, 25(9): 898-916.

Robson, I. and V. Rawnsley (2001). Co-operation or coercion? Supplier networks and relationships in the UK food industry, Supply Chain Management: An International Journal, 6 (1): 39-48.

Ronnenberg, S., M. Graham and F. Mahmoodi (2011). The important role of change management in environmental management system implementation. International Journal of Operations and Production Management, 31 (6): 631-647.

Russo, M. and P. Fouts (1997). A Resource-Based Perspective on Corporate Environmental Performance and Profitability. The Academy of Management Journal, 40(3): 534-559.

Sarkis, J., P. Gonzalez-Torre and B. Adenso-Dias (2010). Stakeholder pressure and the adoption of environmental practices: The mediating effect of training. Journal of Operations Management, 28: 163-176.

Schoenherr, T. (2012). The role of environmental management in sustainable business development: A multi-country investigation. International Journal of Production Economics, 140: 116-128.

Sharma, S. and I. Henriques (2005). Stakeholder influences on sustainability practices in the Canadian forest products industry. Strategic Management Journal, 26: 159-180.

Sharma, S., J. Aragon-Correa and A. Rudea-Manzanares (2007). The contingent influence of organisational capabilities on proactive environmental strategy in the service sector: An analysis of North American and European ski resorts. Canadian Journal of Administrative Sciences, 24: 268-283.

Squire, B., P. Cousins, B. Lawson and S. Brown (2009). The effect of supplier manufacturing capabilities on buyer responsiveness, International Journal of Operations and Production Management, 29 (8): 766-788.

Sroufe, R. (2003). Effects of environmental management systems on environmental management practices and operations. Production and Operations Management, 12(3): 416.

Tabachnick, B. and L. Fiddell (2007). Using Multivariate Statistics. Boston, Pearson Education Inc. 
Tate, W., L. M. Ellram and J. Kirchoff (2010). Corporate social responsibility reports: A thematic analysis related to supply chain management. Journal of Supply Chain Management, 46(1): 19.

Thoumy, M. and S. Vachon (2012). Environmental projects and financial performance: Exploring the impact of project characteristics. International Journal of Production Economics, 140: 28-34.

Vachon, S., A. Halley and M. Beaulieu (2009). Aligning competitive priorities in the supply chain: the role of interactions with suppliers. International Journal of Operations and Production Management, 29 (4): 322-340.

Vachon, S. and R. Klassen (2008). Environmental management and manufacturing performance: The role of collaboration in the supply chain. International Journal of Production Economics, 111: 299-315.

Vachon, S. and R. Klassen (2006). Extending green practices across the supply chain: The impact of upstream and downstream integration. International Journal of Operations and Production Management, 26(7): 795-821.

Webster, S., and S. Mitra (2007). Competitive strategy in remanufacturing and the impact of take-back laws. Journal of Operations Management, 25: 1123-1140.

Wiengarten, F., P. Humphreys, A. McKittrick and B. Fynes (2013). Investigating the impact of e-business applications on supply chain collaboration in the German automotive industry, International Journal of Operations and Production Management, 33 (1): 25-48.

Wong, C., K. Lai, K. Shang, C. Lu and T. Leung (2012). Green operations and the moderating role of environmental management capability of suppliers on manufacturing firm performance. International Journal of Production Economics, 140: 283-294.

Zailani, S., T. Eltayeb, C. Hsu, K. Tan (2012). The impact of external institutional drivers and internal strategy on environmental performance. International Journal of Operations and Production Management, 32 (6): 721-745.

Zhu, Q. and Sarkis, J. (2007). The moderating effects of institutional pressures on emergent green supply chain practices and performance, International Journal of Production Research, 45 (18/19): 433355.

Zhu, Q. and J. Sarkis (2004). Relationships between operational practices and performance among early adopters of green supply chain management practices in Chinese manufacturing enterprises. Journal of Operations Management, 22: 265-289. 